\title{
Modelling and Energy Analysis of Solar Charging Facility for Electric Vehicles in Chile
}

\author{
Scarlett Allende \\ Los Zarzales 1533, Santiago 9270842 . Chile. \\ ssallend@uc.cl
}

\begin{abstract}
This paper presents simulation and energy evaluation of a photovoltaic charging centre intended to supply the demand of 244,000 electric vehicles in Chile. According to the obtained results, the transportation system was feasible from the solar radiation, energy consumption, geographic zone, type of PV farm and other sources. Notably, the studied region has a solar potential to supply $10 \%$ of the total domestic cars existing in Santiago, providing a total energy of $253.723 \mathrm{GWh} / \mathrm{yr}$. Furthermore, based on the study factors, the design of the system consists of approximately 428,590 PV modules and an average power generation of $31.89 \mathrm{~W} /$ hour for one single module. Finally, the configuration of a solar charging facility allows applying a new method of energy supply to electric cars that improves the environmental conditions of the city and encourages sustainable development in the transport sector.
\end{abstract}

Keywords - Electric cars, Photovoltaic, Energy demand, Solar radiation, Design system, Power generation.

\section{INTRODUCTION}

One of the crucial issues addressed in the big cities is the number of petrol vehicles and the pollution produced. There are several reasons to continue improving the transportation system through electric cars that are considered as an alternative solution friendly to the environment. At the same time, electric cars allow the analysis of the potential of the system based on the solar resource of a geographic zone.

Overall, Chile has severe issues of air pollution, of which $30 \%$ is the result of the transport emissions [1]. Therefore, the implementation of innovative technologies of transport and the clean energy generation are crucial to help supply the demand of energy and decrease the levels of pollution in the city.

On the other hand, Chile has enormous potentials in solar energy and consequently in the development of electric vehicles. Currently, the Chilean government has used its their solar potential to create sustainable initiatives, such as the "Electrolinera" project that involves the construction of 14 charging PV centres designated to solar cars [2].

\section{METHODOLOGY}

\section{Estimating Energy Demand}

There are eight procedures to obtain the energy data, as shown in Figure 1. Firstly, the route is selected on the smartphone by a route application (such as "Runtastic"), then it applied driving in a diesel car in the streets in Santiago. After that, the application generated graphs of speed $(\mathrm{km} / \mathrm{hr})$ and altitude (m).

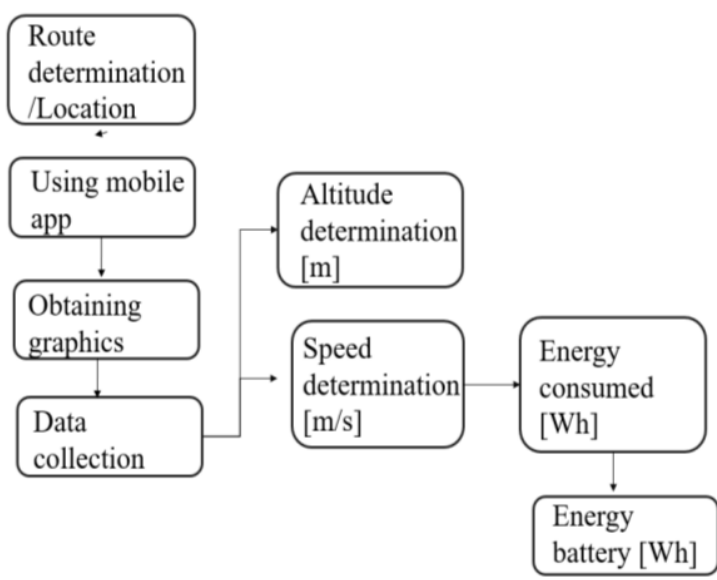

Fig .1 Flow diagram to obtain the energy demanded by the battery.

$$
E=\left[(\mu * m * g * \cos \theta)+(m * g * \sin \theta)+\left(\frac{1}{4} C d * A * \rho *\left(V f^{2}+V i^{2}\right)\right)\right] * \Delta d+\frac{1}{2} * m *\left(V f^{2}-V i^{2}\right)
$$

Eq .1: Energy consumption by the car [3]. 
Where, $m$ : mass of the car; $A$ : Is the frontal area of the car (2.754 $\mathrm{m}^{2}$ [3]),; Cd: is the drag coefficient of the car (with 0.272 [3]); $\mu$ : is the traction efficiency of the surface (0.8 factor [4]); $\rho$ : is the density of air $\mathrm{kg} / \mathrm{m} 3$ $\left(1.225 \mathrm{~kg} / \mathrm{m}^{3}\right.$ [5]); $\theta$ : is the slope angle; $\boldsymbol{\Delta d}$ : Is the difference of distance; $\mathrm{g}$ : is a gravitational constant equal $9.81 \mathrm{~m} / \mathrm{s}^{2} ; V f$ : Final velocity; $V i$ : Initial velocity. At the same time, the angle of the slope is calculated with the altitude data by Equation 2.

$$
\theta=\frac{\left(\tan ^{-1} *(\Delta \text { distance })[m]\right.}{\Delta \text { Altitude }[\mathrm{m}]}
$$

Eq .2: Angle of the slope in radians

At the same time, throughout the route, the energy consumption was variate by the regenerative and traction braking. Therefore, it is necessary to calculate the energy consumption considering ranges of efficient of the vehicle. The function represented in Equation 3. Where, $\eta b c$ : is battery charging efficiency; $\eta d$ : Discharging efficiency; $\eta c$ : Charging efficiency, Et: Energy of traction and Ereg: Energy of regeneration. In this case, it was considered a discharging factor of 0.85 [3], charging factor of 0.7 [3] and a battery charging efficiency of $95 \%$ [3]

$$
\text { Energy }=\left(\frac{1}{\eta b c}\right)\left[\left(\frac{1}{\eta d}\right) E t-\eta c * E_{-} r e g\right]
$$

Eq .3: Total trip energy calculation [3]

Once obtained the value of energy battery (considering regenerative and traction efficiencies), it is necessary continuing with the calculation of average distance and energy consumed, as shown in Figure 2. At the same way, determining the number of electric vehicles is essential, which represents $10 \%$ of the domestic cars existing in the city.

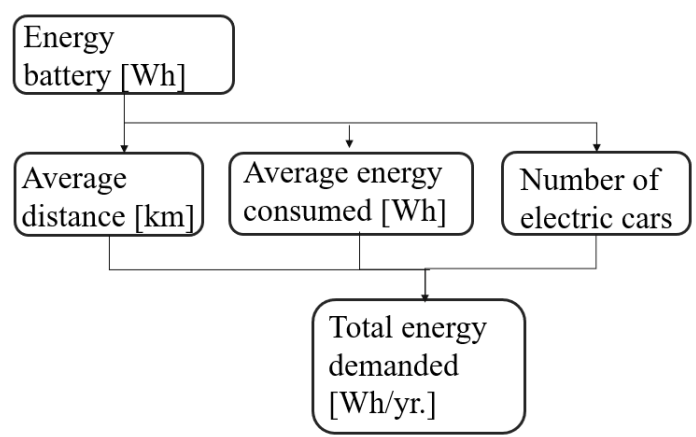

Fig .2 Flow diagram to calculate the total energy demanded.

Following, Equation 4 is used for the calculation of total demand energy, which involves the following factors. $D$ : is the average driving distance $(2.964 \mathrm{~km}) ; n$ : represents the number of electric vehicles (150) and Eavg: is the average energy consumption of an electric car $(961.06 \mathrm{Wh})$. In this case, the number of electric cars considered is represented by the project "Electrolinera" in Chile [2]

$$
E_{\text {total }}=D * n * E_{\text {avg }}
$$

Eq .4: Total energy demand [6]

\section{Calculation of Temperature and Irradiation}

The calculation method performed for the output power of the PV module detailed in Figure 3. Those involve obtaining the data of temperature and solar source. Furthermore, it is necessary to consider PV modelling aspects, such as cell temperature and its efficiency.

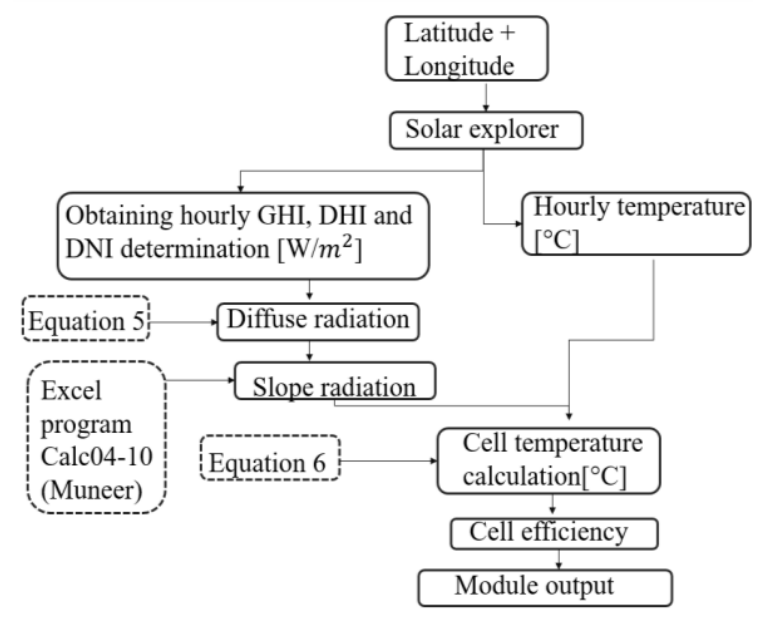

Fig .3 Flow diagram to calculate the module power output.

The first step is to obtain the latitude and longitude by "google map", in this case, it was $-33.52^{\circ}$ and $70.76^{\circ}$, respectively. Then, the coordinates data entered in the solar explorer [7] provide the data of temperature and irradiation by day and hour, in a direct way. With the data of global and direct Irradiation the diffuse radiation can be calculated by the following formula.

$$
G H I=D i f H I+D H I
$$

Eq .5: Calculation of diffuse radiation [8]

Specifically, GHI is the global horizontal irradiation $\mathrm{W} / \mathrm{m}^{2}$, and $\mathrm{DHI}$ is the direct horizontal irradiation $\left[\mathrm{W} / \mathrm{m}^{2}\right]$. With the difference of both Irradiations, the 
diffuse radiation $\mathrm{W} / \mathrm{m}^{2}$ is obtained. Once collecting all the radiations, it was possible to calculate the slope irradiation by Excel program Calc 04-08 (Muneer). After this step, the cell temperature is measured, considering the ambient temperature hourly, slope irradiation and other factors shown in Equation 6.

$$
\begin{gathered}
\mathrm{Tc}=\mathrm{Ta}+\left(\frac{\mathrm{G}_{\text {slope }}}{\mathrm{G}_{\text {noct }}}\right)(\mathrm{Tc}, \text { noct }-\mathrm{Ta}, \text { noct })(1 \\
\left.-\left(\frac{\text { nstc }}{\tau \alpha}\right)\right)
\end{gathered}
$$

Eq .6: Calculation of cell temperature [9]

Where, $G$ slope: Global slope irradiation; Gnoct: 800 W/m2; Tc, noct: Cell temperature at NOCT; Ta, noct: Air temperatures NOCT; $n s t c$ : Cell efficiency at SCT; Ta: Absorptivity of the module and Ta: Ambient temperature.

By Equation 7 is possible to calculate the PV cell efficiency under determinants of temperature fluctuations, efficiency at standard test conditions ( $\eta s t c)$, Cell temperature $(T c)$, Cell temperature under standard test conditions $(T c, s t c)$ and temperature coefficient value $(\alpha p)$ [9].

$$
\eta_{c e l l}=\eta_{s t c}[1+\alpha p(T c-T c, s t c)]
$$

Eq .7: Calculation of cell efficiency [9]

The last estimation is the electrical output power represented in Formula 8, whose factors are $\eta$ mod:
Electrical efficiency under standard test conditions, $A$ : Surface area of PV panel, Gtilt: consists on slope irradiation, and finally, $T c$ : Cell temperature calculated in the step before.

$$
P=\eta_{\text {mod }} * A * G_{\text {tilt }}[1-0.0045 * T c-298.15]
$$

Eq .8: Calculation of output performance [10]

\section{RESULTS}

1. Unit Demand

Firstly, the data collected in the route chosen were a total of $5.7 \mathrm{~km}$ of distance and at a time of 13 minutes and 20 seconds. According to the results, the speed was relative during the driven route with ranges between 0.5 and $16 \mathrm{~m} / \mathrm{s}$, and the average velocity was of $7.62 \mathrm{~m} / \mathrm{s}$.

Figure 4 indicates the different road gradients which variation is between the values 0 to over $400 \mathrm{~m}$. Seeing the definition of altitude in the graph, it can be assumed that the route was ascending most of the time. With this database, it was possible to calculate the angle of the gradient (rad) to obtain energy consumption finally. Besides, the illustration shows the performance of energy consumed on the route. Some of these values are negative due to the retrieved energy which was generated by regenerative braking, and the positive values represent the energy consumed, which involves traction efficiency. The average energy consumption of the trip was of $961.06 \mathrm{Wh}$.

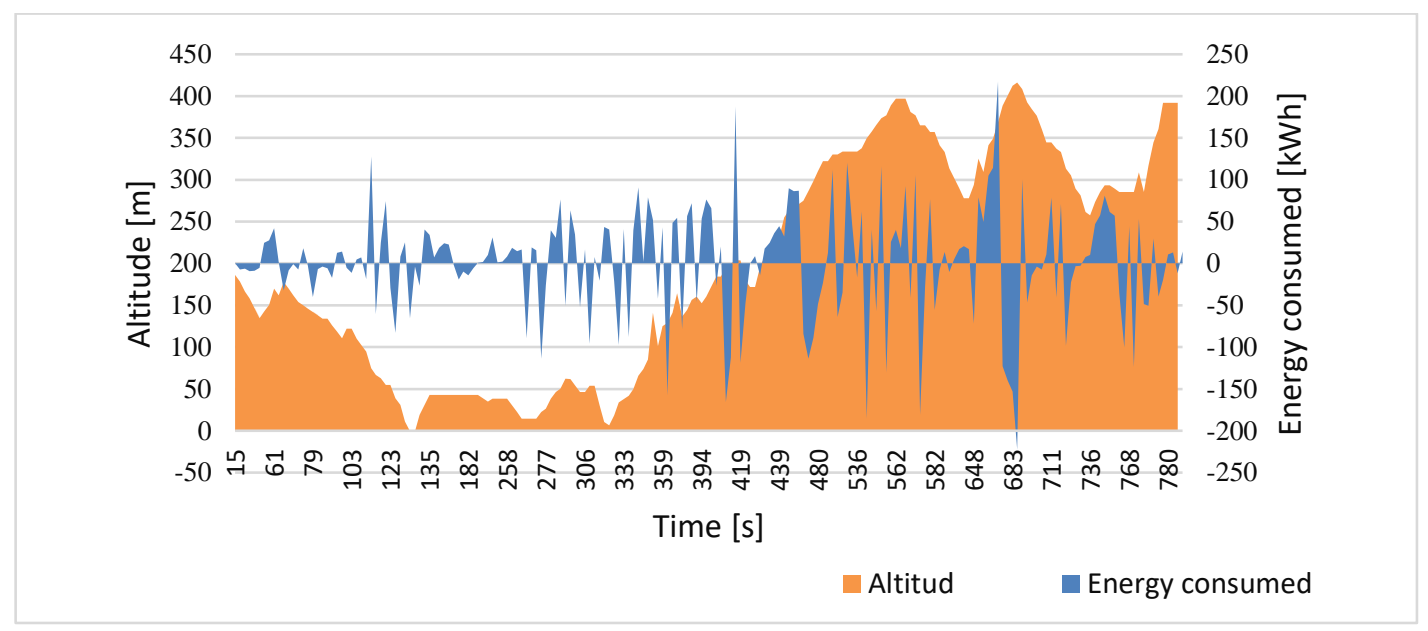

Fig .4 Altitude of the route and energy consumed by the battery.

\section{National Demand}

The total energy consumed per year was 253.7
GWh, considering supplying 244,000 electric cars per year. The details of the performance result can be seen in Table 1. 
Table 1. Summary of Total Energy Demanded

\begin{tabular}{|c|c|c|c|}
\hline $\begin{array}{c}\text { Average } \\
\text { distance } \mathbf{k m}\end{array}$ & $\begin{array}{c}\text { Average E } \\
\text { consumed } \\
\mathbf{W h}\end{array}$ & $\begin{array}{c}\mathbf{E} \text { total } \\
\text { demand } \\
\mathbf{G W h}\end{array}$ & $\begin{array}{c}\mathbf{E} \text { total } \\
\text { demanded } \\
\mathbf{G W h} / \mathbf{y r} .\end{array}$ \\
\hline 2.964 & 961.06 & 0.6951 & 253.7 \\
\hline
\end{tabular}

\section{Calculation of Temperature and Solar Source}

The hourly temperature data were obtained by solar explorer [7] considering coordinate of latitude -33.5 and longitude -70.7 . The days measured by solar explorer were between the dates $1^{\text {st }}$ Jan 2016 and $26^{\text {th }}$ Dec 2016. However, only the data that belong to the $12^{\text {th }}$ day of each month will be considered.

Figure 5 shows the elevated difference between the maximum and minimum temperature during the

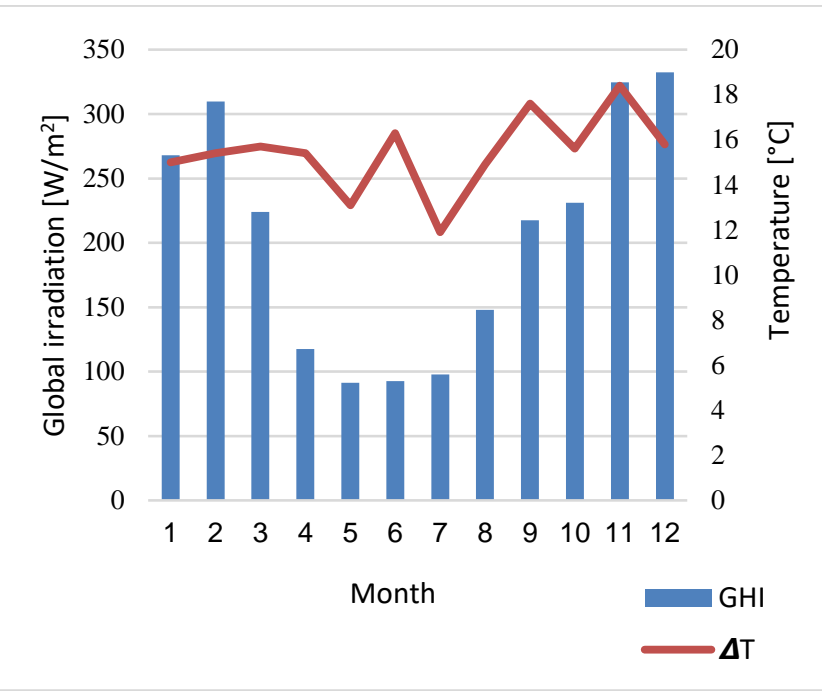

Fig .5 Average hourly corresponding to the global horizontal irradiation $(\mathrm{W} / \mathrm{m} 2)$ and the difference between the maximum and minimum ambient temperature $(\mathrm{W} / \mathrm{m} 2)$ for the entire year. year, which was around $18^{\circ} \mathrm{C}$ in the spring season. A similar procedure was applied to get the hourly irradiations, obtained by the solar explorer [7]. As described in Figure 5 the best radiation performance is in the summerseason (between November and February) with over $300 \mathrm{~W} / \mathrm{m}^{2}$ of global irradiation. In the rest of the months, steady rises and drops exist.

On the other hand, the hourly global irradiation result showed that the maximum average of radiation is between 12 and 16 hours with over $500 \mathrm{~W} / \mathrm{m}^{2}$.Figure 6 describes the minimum performance, which is during morning and evenings when the global radiation declines dramatically. Additionally, it represents the output power of a single PV module, whose peak is at 17 hours with more than $80 \mathrm{~W}$.

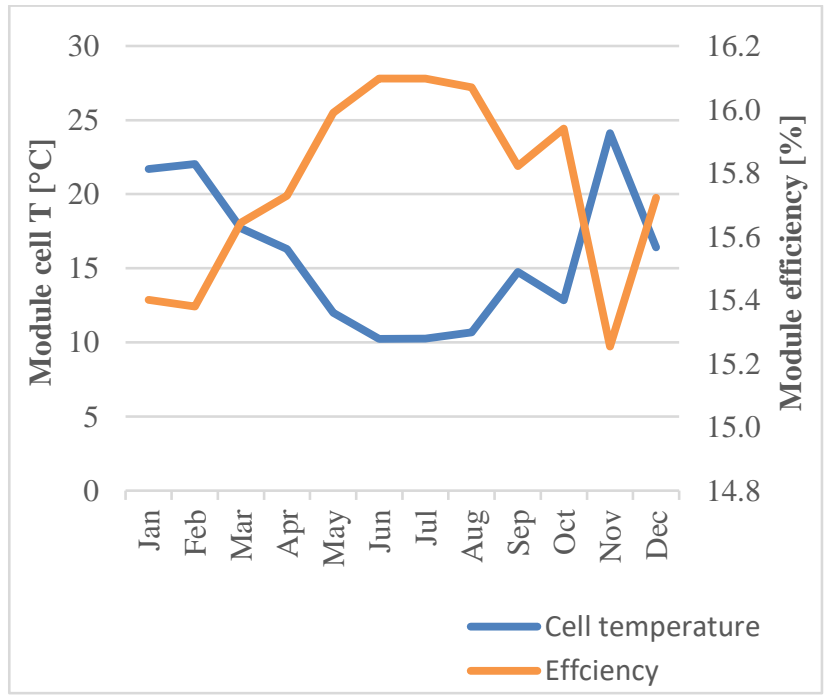

Fig .7 Comparison between cell temperature and panel efficiency.

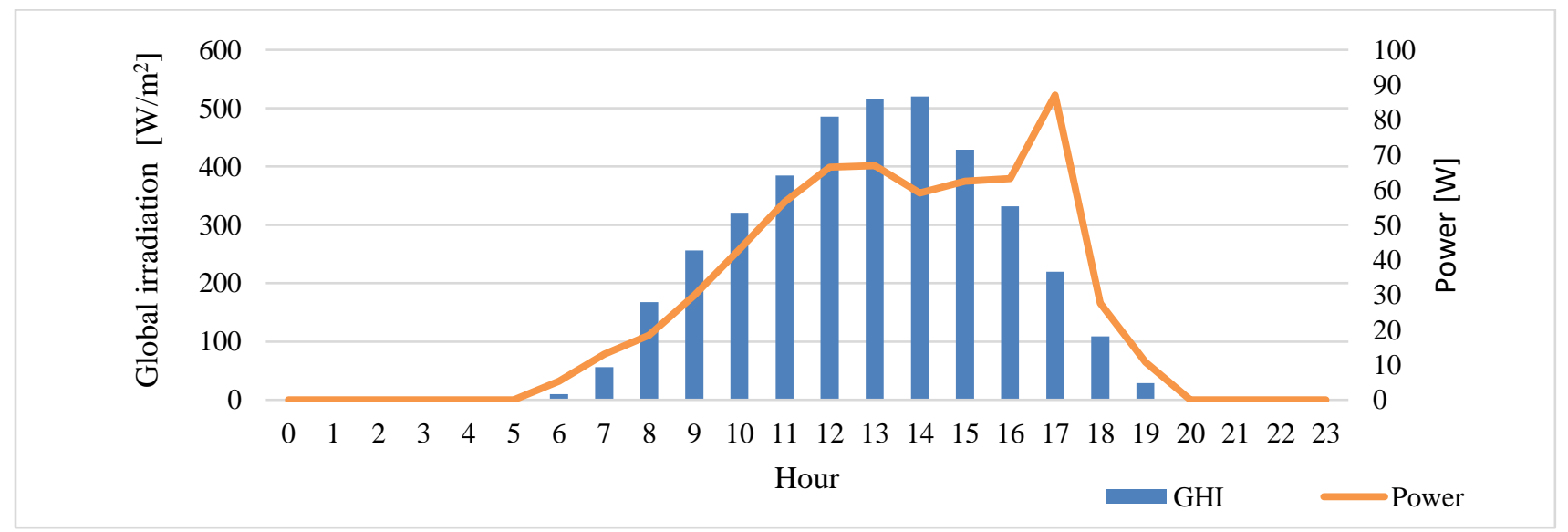

Fig .6 Annual average of GHI per hour $\left(W / m^{2}\right)$ and average of $P V$ output power $(W)$. 


\section{Calculation of Cell Temperature}

After obtaining the temperature and irradiation per hour, the cell temperature was calculated considering the values $\mathrm{G}$ slope calculated previously; Gnoct: $800 \mathrm{~W} / \mathrm{m}^{2}$ [9]; Tc of $47{ }^{\circ} \mathrm{C}$ [11]; Ta, noct of $25{ }^{\circ} \mathrm{C}$ [11]; $n$ stc of $15.2 \%$ [11]; Ta of 0.8 [11] and $\mathrm{Ta}$, calculated earlier. Figure 8 describes the relationship between ambient temperature and cell temperature per hour.
The following result was the calculation of cell efficiency of the PV panel, and it was reached by Formula 7, which involved factors of $n s t c$ of $15.20 \%$; $T c$, stc of $25{ }^{\circ} \mathrm{C}$; $\alpha p$ of $0.40 \% /{ }^{\circ} \mathrm{C}$ and $T c$ calculated in the step before. Figure 7 demonstrates the relationship between cell temperature and panel efficiency.

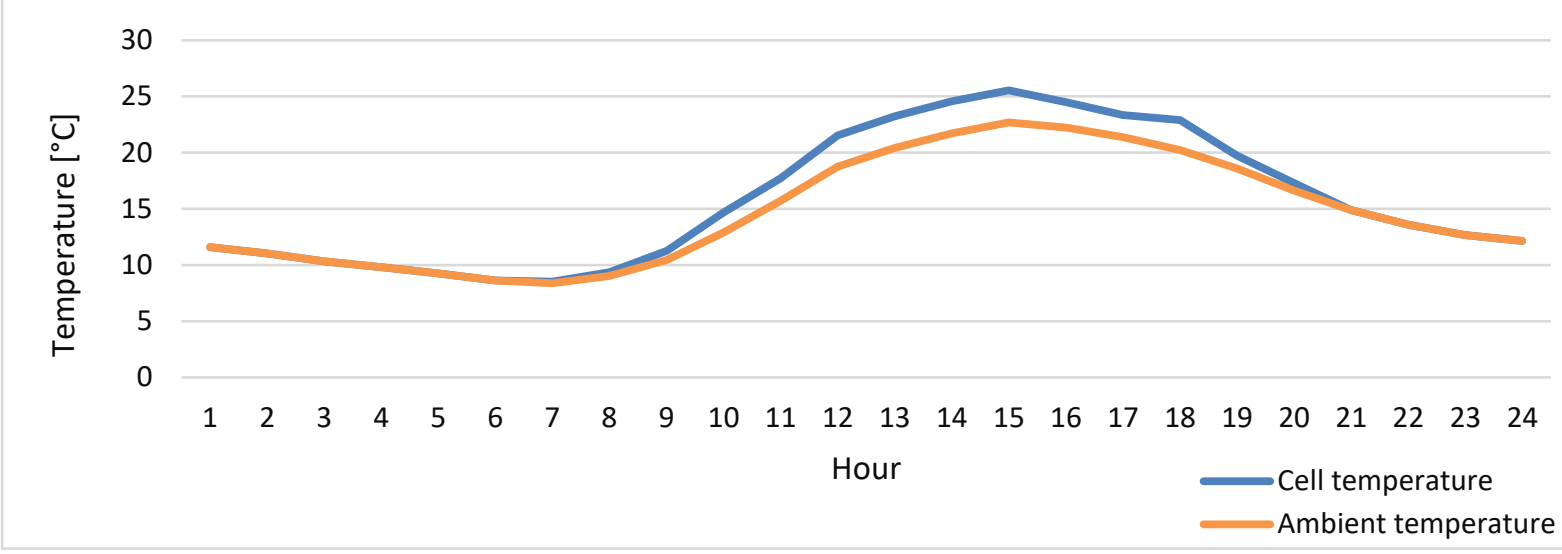

Fig .8 Comparison between cell temperature and ambient temperature.

\section{Determination of the PV System}

\section{A. PV modules quantity}

Firstly, it was necessary to estimate the energy produced by one PV module, through Formula 9. The Equation involves factors of PV surface area $\left(2.6 \mathrm{~m}^{2}\right.$ [11]), the efficiency of the system (15.20\% [11]) and tilted global irradiance $\left(7.92 \mathrm{kWh} / \mathrm{m}^{2}\right)$.

$$
E_{\text {module }}=A m * \cap \text { sys } * \text { Itilt }
$$

Eq .9 : Energy of $P V$ module [3].

Where $\mathrm{Am}$ represents the useful PV area; $\cap$ sys is the efficiency of the system and Itilt is the tilted global irradiance calculated previously. The next step is to calculate the number of PV modules necessary to supply the total consumption, which is obtained by Equation 10.

$$
X \min =\frac{\text { E total consumption }}{E \text { module }}
$$

Eq .10: Number of $P V$ modules.

As a result, Table 2 shows a summary of the number of $\mathrm{PV}$ modules required. The function involves the total energy consumption per year whose value was
$253,723,041.351 \mathrm{kWh} /$ year and the energy produced by one PV module was $591.99 \mathrm{kWh} / \mathrm{yr}$., obtaining $428,590.713$ modules overall.

Table 2. Summary of the Number of PV Modules.

\begin{tabular}{|c|c|c|}
\hline $\begin{array}{c}\text { E module/year } \\
\text { kWh }\end{array}$ & $\begin{array}{c}\text { Total } \\
\text { consumption } \\
\text { kWh/year }\end{array}$ & $\begin{array}{c}\text { Number PV } \\
\text { Module }\end{array}$ \\
\hline 591.99 & $253,723,041.351$ & $428,590.713$ \\
\hline
\end{tabular}

\section{B. Calculation of array size}

Besides, it was necessary to measure the maximum open circuit voltage of the module as shown in Equation 11. The factors are the Voc that is open circuit voltage; $T d c u$, mod that represents the temperature voltage coefficient $\left(0.4\right.$ [11]) and $\Delta$ Tlow $\left(-13.1^{\circ} \mathrm{C}\right)$ which is the difference between the ambient temperature (7.5 ${ }^{\circ} \mathrm{C}$ ) and $T c$, stc $\left(25^{\circ} \mathrm{C}[11]\right)$. As a result, the maximum voltage in the open circuit is $55.45 \mathrm{~V}$.

$$
V d c \max \bmod =V o c *\left(1+\left(\operatorname{Tdcu} \bmod * \frac{\Delta T l o w}{100} \%\right)\right)
$$

Eq .11: Maximum voltage in open circuit [12]. 
At the same way, the minimum voltage in an open circuit can be calculated by Formula 12. Where, Vmpp is the maximum power of the PV module (49.25V); Tdc mod is temperature voltage coefficient (0.4) and $\Delta T$ Tmax $\left(3.5^{\circ} \mathrm{C}\right)$ represents the difference between the Tmax, mod and $T$ sct. The minimum voltage open circuit is $49.94 \mathrm{~V}$.

$$
V d c \min \bmod =V m p p *\left(1+\left(T d c \bmod * \frac{\Delta T \max }{100} \%\right)\right)
$$

Eq .12: Voltage minimum in open circuit [12].

Analogously, the maximum current of PV module was calculated by Equation 13, which involves the shortcircuit current (I sc of 7.92A [11];); current temperature (Tdc, $\bmod$ of 0.05 [11]) and the difference between the maximum module temperature and STC temperature, represented by $\triangle \operatorname{Tmax}\left(3.5^{\circ} \mathrm{C}\right)$. The Imax open obtained was of $7.93 \mathrm{~A}$.

$$
\operatorname{Idc} \max \operatorname{str}=\mathrm{I} \mathrm{Sc} *\left(1+\left(\operatorname{Tdc} \bmod * \frac{\Delta \mathrm{T} \max }{100} \%\right)\right)
$$

Eq .13: Maximum current of PV module. [12].

Then the minimum number of strings was calculated through Equation 14, whose factors are: maximum power generated ( $P$ dcgen); the maximum power of the module $(P \max , \bmod )$ and the number of strings per module ( $\cap \bmod$ str). The calculation considered a $P$ max of $54400 \mathrm{~W} ; P \max \bmod$ of $13.9 \mathrm{~W}$ and $\mathrm{n} \bmod$ of 18 modules, obtaining a minimum number of strings of 217.

$$
\cap \min s t r=\frac{P \text { dcgen }}{P \max \bmod * \cap \bmod s t r}
$$

Eq .14: Minimum number of strings [12].

Finally, the total number of inverters was obtained by Equation 15, which includes the number of $\mathrm{PV}$ modules ( $\cap$ mod of 3905.2) and the total number of strings ( array of 428,591 ). In this case, the total of inventers was 110 .

$$
\cap i n v=\frac{\cap \bmod }{\cap \text { array }}
$$

Eq .15: Total number of inverters [12].

\section{Designing the $P V$ facilities}

The PV charging zone proposed in Santiago was located mainly in the western region of the city. The solar facilities placed around $2 \mathrm{~km}$ of distance from the route done. The place has plenty of areas available and no risk of obstruction of radiation. The availability of solar PV installation is $1,008,000 \mathrm{~m}^{2}$.

Around $60 \%$ of the mentioned area belongs to the PV facilities $\left(576998.7437 \mathrm{~m}^{2}\right.$ of a useful area), and another $20 \%$ of the surface is left unoccupied to allow the maintenance between PV panels, which is $201,600 \mathrm{~m}^{2}$. Furthermore, the PV modules installed will have a $45^{\circ}$ inclination and orientated towards the north. According to the previous calculation, each charging station will have 18 rows and 57 columns. Also, the arrangement of 217 strings connected in parallel with 18 modules connected in series is considered. At the same time, one inverter manages 57 PV panels of one total of 428,591 PV modules.

\section{CONCLUSION}

According to the transport and environmental plans of the Chilean government, the pollution problem is expected to be resolved. One alternative is by the promotion of solar charging facilities of electric cars, providing electricity for $10 \%$ of the national car fleet in Santiago. Specifically, the study demonstrated the following findings.

- The energy consumption has a direct relationship with the type route (altitude) and the speed. That is because in some parts of the road the cars needed acceleration and in other deacceleration, causing more demand for energy consumption in the point of high altitude than others. At the same time, this produced an effect of regenerative braking and traction efficiency, which means negative and positive values of energy consumption.

- Overall, the solar analysis demonstrated that temperature and irradiation have a direct relationship. The maximum level of radiations is the summer season with maximum average values of global radiation of $340 \mathrm{~W} / \mathrm{m}^{2}$. Showing enough potential to supply the PV system.

- On the other hand, the results showed that throughout the day the solar module increases its temperature considerably, around $13 \%$ more than ambient temperature, between hours 15 and 16 .

- At the same time, the cell efficiency was decreased by approximately $4 \%$ when the cell module got the maximum value of temperature. This period was 
between October and November. However, global competence represents an excellent performance for the system.

- The best power performance of the PV module was between hours 18 and 19 (over $80 \mathrm{~W}$ ), increasing the output power by $27 \%$.

- To supply the energy required is necessary to count for the excellent PV facilities. In this case, the installation of $428,590.713$ photovoltaic modules and the integration of $20 \%$ of the area in the solar facilities, whose objective is maintenance of work and reduction the possibilities of obstruction in solar radiation are a must.

\section{REFERENCES}

[1] G. Aymeric and S. François. "Case study for Chile: The electric vehicle penetration in Chile," in Electric Vehicles: Prospects and Challenges, 2017, pp. 245-285.

[2] J. M. Vilches. "Emol," 2017. [Online]. Available: http://www.emol.com/noticias/Tecnologia/2017/0 7/13/866601/El-panorama-de-los-autoselectricos-en-Chile-Cuantos-son-y-donde-secargan.html. [Accessed 1st Oct 2018].

[3] T. Muneer, R. Milligan, I. Smith, A. Doyle, M. Pozuelo and M. Knez. «Energetic, environmental and economic performance of electric,» Transportation Research Part D: Transport and Environment, Vol.35, pp 40-61, 2015.

[4] CausaDirecta. (2013) "Investigación y reconstrucción de accidentes de tráfico." [Online]. Available:

https://causadirecta.com/especial/calculo-develocidades/tablas/tabla-de-factores-derozamiento-del-pavimento-para-neumaticos-degoma. [Accessed 8th Oct 2018].

[5] WindPower. (2003) "Danish wind industry associacion" [Online]. Available: http://xn-drmstrre-64ad.dk/wp-

content/wind/miller/windpower\%20web/es/tour/wr es/enerwind.htm. [Accessed 8th Oct 2018].

[6] D. Goos. "Feasibility study of a solar charging facility for electric vehicles in Munich." Master thesis, School of Engineering \& the Built
Environment Edinburgh Napier University, Edinburgh, 2015.

[7] Facultad de ciencias físicas y matemáticas, Universidad de Chile, "Explorador solar," 2018. [Online]. Available: http://ernc.dgf.uchile.cl:48080/exploracion.

[Accessed 11 Oct 2017].

[8] R. Escobar, J. M. Cardemil, C. Cortés and A. Pino, "Atlas solar de Chile," Pontificia universidad católica de Chile, Santiago, 2013.

[9] M. Jeffrey, I. Kelly, T. Muneer and I. Smith, "Evaluation of solar modelling techniques through experiment on a $627 \mathrm{kWp}$ photovoltaic," School of Engineering and Built Environment, Edinburgh Napier University, Edinburgh, 2015.

[10] D. a. Beckmann, Solar engineering of thermal process, Madison: University of Wisconsin, 1991.

[11] Advanced Solar Photonics. "ASP-400GSM Smart moduletm series - high efficiency frameless monocrystalline solar modules". (2012). [Online]. Available:

https://www.enfsolar.com/Product/pdf/Crystalline/ 50bd9203a2fc0.pdf. [Accessed 1st Oct 2018].

[12] S. Allende. "Energy Analysis of a Solid Oxide Fuel Cell (Sofc) Operated by PV System in the Residential Sector, in Highland." Master thesis, School of Engineering \& the Built Environment, Edinburgh Napier University, Munich: GRIN Verlag, 2018.

[13] S. Henriquez, "Red de electrolineras ya cubre en forma continua desde Coquimbo a Biobío".(2019). [Online]. Available: http://www.economiaynegocios.cl/noticias/noticia s.asp?id=550309. [Accessed 1st Mar 2019].

[14] Comisión Nacional de Energía. (2015), "Informe costos de inversión por tecnologia de generación". [Online]. Available: https://www.cne.cl/wpcontent/uploads/2015/11/Informe-Costos-deInversi\%C3\%B3n-Tec-de-Generaci\%C3\%B3nAgo-2015.pdf. [Accessed 1st Oct 2018].

[15] Comité Nacional, Gobierno de Chile (2017). "Estudio Benchmarking de plantas solares 
fotovoltaicas en Chile." [Online]. Available: http://www.comitesolar.cl/wp-

content/uploads/2017/04/Informe-BenchmarkingPlantas-Solares-

Fotovoltaicas_actualizaci\%C3\%B3n.pdf. [Accessed 16th Oct 2018].

[16] Asociación Chilena de energias enovables. (2017) "Energía solar: prometedor futuro para chile" [Online]. Available: http://www.acera.cl/energia-solar-prometedorfuturo-para-chile/. [Accessed 1st Oct 2018].

[17] M.Gutierrez. (2017). "Economía y negocios." [Online]. Available: http://www.economiaynegocios.cl/noticias/noticia s.asp?id=341770. [Accessed 8th Oct 2018].
[18] J. V. F. Serra. «Electric vehicles: Technology, Policy and Commercial Development,»1st ed. London: Routledge, 2012..

[19] M. Mruzek, IgorGajdáč, L'. Kučera and D.Barta. «Analysis of Parameters Influencing Electric Vehicle Range,» Procedia Engineering, vol. 134, pp.165-174, 2016.

[20] E.S. Rubin and C.I. Davidson. Introduction to Engineering and the Environment, 1st ed. Boson: McGraw-Hill, 2001.

[21] T. Muneer, C. Gueymard and H. Kambezidis. Solar Radiation and Daylight Models, 2nd ed. Amsterdam: Elsevier, 2004. 